\title{
"I saw souls": remarks on the theory and practice of intercultural and interfaith spiritual care ${ }^{1}$
}

\author{
"Eu vi almas": notas sobre a teoria e prática do \\ cuidado espiritual intercultural e inter-religioso
}

\section{Helmut Weiss}

Pastor e supervisor de ensino da Associação Alemã para a Psicologia Pastoral, especialista em pastoral e aconselhamento, fundador e presidente da Society for Intercultural Pastoral e Aconselhamento SIPCC, e-mail: hewe.sipcc@t-online

\section{Abstract}

In this article the author presents a short overview on the theory of intercultural and interreli-gious pastoral care and counseling. He is giving some explanations about the multicultural situation in Europe, the "synthetic" personality and some definition of interculturality. After describing language and culture as "soft" concepts, religion as a "sign language" and giving some remarks to intercultural and interreligious competencies, he brings an example of a con-versation with a patient in a German hospital to

1 In this essay I have used parts of my article "Interreligious and intercultural pastoral care and counseling. Notes from a German perspective" in: Daniel S. Schipani and Leah Dawn Bueckert (editors) Interfaith Spiritual Care. Understandings and practices; Pandora Press, Kitchener, Ontario, 2009. 
give some insight into the practice of intercul-tural and interreligious pastoral care and counseling. He is ending with presenting a few theo-logical thesis.

Keywords: Interreligious and intercultural pastoral care and counseling. Interculturality. Religion. Culture. Intercultural and interreligious competencies.

\section{Resumo}

Neste artigo, o autor apresenta um breve resumo da teoria do cuidado e aconselhamento pas-toral intercultural e inter-religioso. Descreve a situação multicultural na Europa e define, sinteticamente, alguns conceitos básicos do aconselhamento inter-religioso e intercultural tais como: personalidade; interculturalidade; linguagem e cultura; religião como linguagem simbólica. Após discutir as noções de competência inter-religiosa e intercultural, o autor traz o exemplo de uma conversa com um paciente num hospital na Alemanha para, a partir daí, lançar algumas luzes sobre a prática do aconselhamento pastoral intercultural e inter-religioso. O autor conclui com a apresentação de algumas teses teológicas acerca do tema em discussão.

Palavras-chave: Cuidado e aconselhamento pastoral intercultural e inter-religioso. Interculturalidade. Religião. Cultura. Competência inter-religiosa e intercultural.

\section{Towards an Intercultural and Interfaith Approach to Pastoral Care and Counseling}

Until the last couple of decades, pastoral care and counseling focused in Europe on people of one confession, with a few exceptions. The teaching of the Roman Catholic Church formed the center of the unified worldview of the Middle Ages; the church alone mediated salvation. Following the Reformation and the formation of the reformed churches, it was not common for pastoral care to be given to those belonging to other denominations. Even in hospitals and social institutions where people of various confessions lived next to one another, everyone had their own clergy. Catholic priests visited Catholic patients in the hospital 
and the Lutheran and Reformed went to the beds of their sick or their inmates of prisons. It has only been in the last two decades that there have been modest efforts towards cooperation and ecumenical pastoral care and counseling between the churches. So it is not surprising that there is very little tradition of intercultural or even interreligious pastoral care and counseling in many European countries, because both are only in their beginning stages.

At the same time, because Europe has experienced significant demographic changes, it has become necessary to develop forms of pastoral care and counseling that recognize people in their cultural and religious diversity and adjust to them. Through the arrival of workers and their families from other countries, e.g. Turkey, or continents like Africa and Asia starting in 1960, a quite great percentage of the population is now immigrants with quite different cultures, languages and religions.

All these people have a biography which is permeated by many influences and faiths. They are persons who could be called "synthetic", "Creole" or "syncretistic". There is nothing "pure" in it. In some aspects, it is not clear to where they are to belonging, to their home-land, to their traditional culture or to the land they are living in with its culture; in other aspects they can have many different affiliations. Lately, the expressions "hybrid worlds" or "hybrid personalities" have been used in this context, hybrid as an expression for beings that are composed of many different substances and thereby acquire a new identity. The Israeli psychologist Dan Bar-On (BAR-ON, 2003, p. 27) has dealt with the question of the identity of groups and individuals and has shown the difficulties of "monolithic" identities, taking Israel as an example - i.e. an identity that appears to be without ambiguity. "Monolithic identities" are difficult because they are no longer open and, thus, a dialogue with others is nearly impossible.

For migrants or citizens of multicultural societies syntheses are vital - but are not everyone's culture, language and religion a composition of various influences to a greater or lesser extent? And is not every society in our global world multi-ethnic, multi-lingual, multi-cultural, multifaith and so on?

In such a context we cannot assume, that there is only one type of care and counseling. There are a variety of answers offered by very 
different religious beliefs and worldviews to help all kinds of people with different lifestyle find meaning. Pastoral counseling competes with psychological, philosophical, esoteric and atheistic guidance, with care offered by Jews, Muslims, Buddhist and other religions. Many societies in Europe still need to adjust to this sort of diversity, which has been taken for granted in other countries much earlier.

To take up the task of discussing intercultural and interfaith counseling the Society for Intercultural Pastoral Care and Counselling - SIPCC (www.sipcc.org) was founded in 1995. Constant encounters with people from many countries with different cultures and religions pose new questions for pastoral care and counseling, such as, how we can discern the various cultural and religious contexts. The challenge is to realize that people from different corners of the world could belong to completely different cultures and religions, completely different classes and races, to completely different casts and ethnicities. That makes interculturalism a challenge for interpersonal relationships in this diversity, for the co-existence of societies, for political and economic designs, for cultural participation and religious appreciation.

In intercultural encounters, one can quickly discover that despite all the similarities that can be experienced, there are still significant differences. Again and again, these differences are emotionally straining and strenuous. Those who engage in intercultural and interfaith meetings and dialogue need intercultural and interfaith competences. They are demonstrated less by rational understanding of other cultures and accommodating other conventions and customs than by enduring the emotional tension, by recognizing conflicts and being willing to withstand them and make them tolerable. It is a special experience when one is successful in resolving conflicts in diversity. These considerations are also decisive in interreligious dialogue. Intercultural competence also means being able to engage in encounters with strangers and listen to them. Interculturalism is precisely the opposite of blocking off a stranger; it is the encounter and discovery of the foreign.

The SIPCC has been intensely involved with questions concerning the meaning of culture for pastoral care and counseling. As a vital context, culture cannot be disregarded in one's perception of peoples' 
situations and the way they interpret their lives. Issues of interculturalism and the definition of intercultural pastoral care and counseling are being deliberated and discussed in the SIPCC. Approaches to a hermeneutic of intercultural communication have been developed. Which types of intercultural expertise are necessary for pastoral care and counseling and for interreligious dialogue are been discussed. Interreligious issues are moving more and more into the spotlight.

The Handbook of Intercultural Pastoral Care and Counselling from 2002 (WEISS, 2000, p. 36) expresses this in the following way:

\section{Interculturalism}

- describes encounters and exchanges between cultures - while preserving one's own cultural identity;

- perceives and appreciates cultural diversity in people, ethnic groups and subgroups - which is especially important in times of globalization and cultural assimilation;

- recognizes that people are similar in many ways - and for that reason works on overcoming racist, sexist and other inhuman attitudes;

- challenges us to recognize foreignness and engage in dialogue;

- exposes how many people, cultures and ethnicities influence each other - and forces us to critically examine our own lifestyle;

- encourages us to encounter people of other cultures in our own neighborhoods with less fear, fewer prejudices and to be more helpful;

- views every individual person as distinctive with inherent worth.

\section{Intercultural pastoral care and counselling}

- connects interculturalism with religious truths, Christian faith and psychological insights; 
- helps people who work in pastoral care, counseling, therapeutic and other helping professions connect their professionalism with their cultural identity;

- develops approaches and methods to offer support and being there for people from various cultures in a competent and professional way.

In my opinion, we still need more involvement in understanding culture and religion. I want to elucidate this briefly.

\section{Culture and language as "soft" concepts}

In order to understand the phenomena of culture and language, I would like to briefly point out three different conditions under which the human beings live (AUGSBURGER, 1986, p. 48-78):

a) Human beings have many things in common and are all equal.

b) Some human beings have some things in common and are similar to some others.

c) Each human being is an individual and is like no one else.

The fact that we as human beings are all equal biologically and that we theologically speaking are all God's creation says an emphatic No to despising or degrading people who are different. And there is one more point: All people have a culture, all people are able to use a language.

Each person shares with some others a certain family, a certain society, a certain language, a certain culture and other things.

Each human being has their particular uniqueness, born at a certain place, at a certain time with a particular biography and with their own end of life.

Culture, language and religion happen in a communal setting, i.e. where human beings have some things in common and are similar to some others. Culture as the "second nature of the human being" shape the general human and natural realities - also such general phenomena 
as birth and death, language and the constitution of one's world, sexuality and one's emotional life. So far, we have spoken of, i.e. interpreted, humaneness only in terms of culture, no matter in which setting. On the other hand: Each human being is not simply a product of a given culture but interprets and shapes the same in their own individual way. Also here, we will be unable to find "purity" but only syntheses of the different settings in which life occurs.

For a long time, culture used to be defined as the sum of human works and values and as the human endeavour to establish certain values within a group. If a community created material and spiritual values, you used to speak of culture. By this, culture became a distinct and incommensurable worldview of an ethnic group, almost an ontological "thing", re-created in constant processes. This held the danger of subsequent degradation of cultures that were different from one's own.

In the meantime, a different concept of culture has become accepted, which, in my opinion, is more useful: i.e. culture as a "thick description" of meaning to guide human social behaviour (GEERTZ, 1973, p. 5-6, 9-10). According to this concept, culture does not create fixed worldviews but tries to find meaning according to which people may behave. People enter into a social discourse, in order to interpret the world in relation to their own behaviour; people successfully try and find languages in order to create images to explain their experiences through symbols which they have discovered as being essential for their behaviour and their actions. They construe a meaning of the world so that they may have an orientation in this world. Here, culture is very closely connected with language as a system of symbols - and culture and language are perceived as a construct which enables people to shape their social life.

Against this background, culture is no longer a 'fixed worldview', but interpretation enhancing social behaviour - i.e. "software" instead of "hardware", to use terms from the culture of computers. With such an understanding, culture defines itself on the basis of the functions of a community and does not subordinate community to pre-existing values.

To me, the question of how culture is understood is important for the question of whether culture and language are capable of being helpful in coming to terms with differences. If cultures are like ontological 
phenomena, the question of which 'fixed worldview' is 'the more highly developed' will be asked - resulting in a power struggle about the sovereignty and domination of definitions among cultures and languages. Then, a struggle will begin about questions such as: Which is the defining culture to which other cultures are to subject themselves or into which they are to be integrated? Which language will be in force among the diversity of languages and systems of symbols?

When culture is based on the question of which "thick description" and which interpretation of the world is considered essential for social behaviour, when the helpful systems of symbols need to be re-created continually, then all those concerned will have the right and the opportunity to join in the communal discourse and to join in shaping respective processes. Then, the point is not to enforce traditions or pre-existing systems, but to explore over and over again which are the communal tasks on hand and which of the "thick descriptions" are suitable and necessary for their implementation.

\section{Religion - a sign language creating identity}

In order to define religion more closely, I turn to the Internet, as is the fashion. Google offers 191,000,000 entries for the headword "Religion". From there, I go to Yahoo. There, I find a category: "Society and culture / religion and spirituality". I proceed to "Religious faiths and practices". There, you can find 64 different categories, for instance "Christianity", "Fire walking", "Theosophy", and "Tenrikyo". My confusion is complete.

I turn to Wikipedia, a universal encyclopaedia on the Internet, and surf for "Religion". I am surprised: The text in German is completely different from the text in English. And again, I am offered various definitions, so there still is no clarity.

The conclusion I draw from my search on the Internet is the following: When "Religion" is spoken about, it may happen that people end up more confused than informed. Therefore, when speaking about religion, it is important to make clear what I am speaking about. Consequently, it is essential for me as Christians to clearly state which elements of religion 
are indispensable for me. And at the same time, it is important that I am not allured into thinking that my opinions might be comprehensible or even obligatory to others.

Following the interesting but unsuccessful trip into the virtual world of the Internet, I resort to a book I recently read: Gerd Theißen, Die Religion der ersten Christen - Eine Theorie des Urchristentums (The Religion of the first Christians - A Theory of early Christianity). This recognized commentator of the New Testament writes, "Religion is a cultural system of signs promising more life quality in correlation to an ultimate reality" (THEISSEN, 2001, p. 19). With this, he explicitly says: Also religion is made into a system of signs by discourse in a certain cultural environment - comparable to culture. Like culture, religion aims at structuring life and amelioration of life. And then follows the crucial and decisive criterion: Religion finds a language of signs and symbols "in correlation to an ultimate reality". Religion is connected with culture, but it is different from culture, it is oriented towards an "ultimate reality", a reality which reaches beyond our reality as we experience it and explore it.

If we now ask the question of what contribution religion makes in the discourse of creating culture, we receive an answer here: It is religion with its correlation to an ultimate reality that urges us to continue in the processes of communication between the "different" and the "others", to continue to look for and to try out new symbols and languages which correlate to the needs of the people and the dynamics of the ultimate reality. The ultimate reality which we understand as being God is the challenge when we ask about more quality to life in a particular life situation. It is religion in particular which makes us transcend our human and cultural possibilities again and again.

Religion as a "system of signs" takes several forms of expression. Theißen names three: myth, rite, and ethos. Myth: Narration of the ultimate reality. Rite: Embodiment of the ultimate reality. Ethos: Behaviour in correlation to the ultimate reality.

So, we as Christians will continue to tell the stories of Jesus Christ and of the great acts of God in our world and in our lives. Also here, we find a strong narrative component. 
In liturgies and holy rituals and symbols, such as baptism and the holy Eucharist, we will demonstrate what happens between God and human beings - here we have an aesthetic and a playful component.

We will orient our social behaviour on God's behaviour towards us here we have an ethic and a moral component.

In the course of their history, communities of faith have interpreted and developed systems of symbols and it is good when they become identifiable and when their characteristics can be read like on an identity card. When Orthodox Christians focus on certain symbols, like the adoration of God in their holy liturgy, this makes discourse easier and more open. Or when the Pentecostal churches regard baptism with the Holy Spirit as so valuable that it becomes the characteristic of their faith.

However, if such signs are made into the ultimate reality itself and if they take the place of the First Commandment and if no other signs are allowed beside them, then the ultimate reality will become obsolete and disintegrate.

I consider it a great gift that in Europe cultures with their community and state institutions exist side by side with religion, so that you can make a difference between what is state, society or religion. This is not the case in all the countries in the world. In some countries, religions have become agencies of the state and of the society, in others, the state has become an agency of religion.

I consider it appropriate, when for example in Germany religious action and life is required to comply with our Constitution. Our constitution proscribes that one religion claims absoluteness, even if such a claim might be basically part of it. Religions - that means also all the Christian churches - are not mandated to exercise power and to assert their own interests. It is their mission to orientate themselves towards more life quality for the people, more life quality for societies and peoples, and more life quality for the whole of creation. The "Conciliary Process for Justice, Peace and the Integrity of Creation" has its roots in Europe and it challenges us to continue its work. If religion is not committed to such holistic and concrete amelioration of life quality, then it is not in correlation to the ultimate reality. Those powers in Europe which have no interest in religion or oppose it with scepticism and enmity bring this to mind 
clearly. We must be grateful to have them, for they help us make our task all the more obvious.

Religion as a community's language of signs and symbols has a great cultural relevance and, yet, transcends culture. This is what makes for the character of religion as being serving and not ruling. Orientated towards more life quality, religion becomes relevant to human beings.

Therefore it is important for us, at the levels of neighbourhoods and at the levels of institutions, that we learn to listen and read with a better understanding what other systems of signs want to communicate.

\section{Inter-cultural and interfaith communication and competences}

When different languages, cultures and religions live together or meet face-to-face as different languages of signs, there always arises the issue of power. Which system of signs "calls the shot", which system of signs holds the power of definition, i.e. determines meaning?

When people of different languages, cultures and religions enter into a relationship, who determines language, which culture dominates, which religion correlates the closest to the ultimate reality - i.e. is the closest to "the truth"?

There are different possibilities of resolving the issue of power:

a) A ruler or a ruling class determines language, culture and religion These practices were applied in the Europe of kings and emperors often. From the $20^{\text {th }}$ century, we know such practices from totalitarian regimes, which to this day have not totally vanished in some places - even in Europe.

b) A cultural or ideological superstructure is created to reach across the differences

Here, I would like to give two very different examples: The USA, with their Declaration of Independence in the year 1776, established new principles by which the differences of future immigrants are relativized by way of introducing a superior understanding of a 'fixed worldview'. The "American Way of life" with its interpretation 
of human life "that all men are created equal; that they are endowed by their Creator with certain unalienable rights; that among these are life, liberty, and the pursuit of happiness" connects all the people, no matter what their origin. You could almost speak of an American religion with a great sense of mission.

The second example is Yugoslavia. Even for me as a historical and political lay person, the following is obvious: After the collapse of the Habsburg Empire after World War I and after the attempts to create political and public structures in its aftermath determined by language and religion, it was Tito with his particular implementation of the communist ideology who was finally able to bridge over the differences between the various ethnicities on the Balkans. In a harrowing way, these differences have erupted again after the collapse of communism. To this day, the issue of power has not been resolved. In these conflicts, religion played a crucial role - and prevents social life and reconciliation in some places even today.

c) Ruling majorities decide, minorities have to subordinate To this day, this tendency can be observed in many places. Protection of minorities with regard to language, culture and religion remains to be a challenge for Europe, which does not always succeed.

d) Resolving the issue of power by way of constant efforts in relationship-building and in communication

This is the path Europe has been trying to go at a political level through the European Union. It is debatable whether it has been successful or not.

I think, for Christians, there is no other way to cope with differences than to enter into a discourse with each other, to listen to one another and to look into the possibilities of collective styles.

This path is not really easy as differences have a habit of causing irritation. Encounters with other people, with the alien, cause irritation at different levels: As my own interpretations stop being a given, emotional insecurity arises, which may be slight or strong. 
To give an example: I enter a foreign country with a foreign language and foreign currency - and my insecurity begins because I no longer recognise the value of things. I do not understand the language - a great bewilderment. I cannot communicate any longer - even children become desperate when they feel they are not being understood or listened to. Such bewilderment may grow into fear, fear of the alien, fear of others.

Inter-cultural communication teaches us that it is very important not to ignore or gloss over such bewilderment but to take notice of it and to integrate it into the communication process. Fact is that communication happens at the emotional level. The pioneers in the research of human communication already knew: Communication does not happen at the content level, but at the level of relationship (WATZLAWIK, 1974, p. 53). Or in other words: Communication with strangers or any other person is first and foremost an act of relationship- building. Once a relationship has been created, an exchange about content is possible. If the relationship is not clear, you can hardly expect to settle on contents.

Communication between different systems and different persons starts with the acknowledgement that we are all different - it starts off from the difference. If there is consent between systems or people or if they have been coalesced, if there is no vis-à-vis, there is no need for communication.

However, one important element of communication is that the parties involved in the discourse should introduce themselves and present their respective positions as openly as possible. Is that not what we do in our everyday life? We meet someone we do not know - we introduce ourselves. This means: Those involved in the communication process must be given the opportunity of presenting their position. In intercultural communication, all those involved must be allowed space to talk about themselves.

Another principle of intercultural communication is: Every participant must be given a chance to speak of her-or himself. No one has a right to dictate how others should understand or describe themselves. No one has a right to determine or define my position. I have no right to define the position of others.

Yet, presenting one's own position is only a beginning. It is equally important to learn about the other person's position by listening to them. One prerequisite in communication between people who are different is 
to adopt an attitude of an attentive reader, of a listening therapist, or of an exploring ethnologist: With a great openness and with searching curiosity, I try to understand how the person who is speaking interprets her - or himself.

Both, when we speak of ourselves and when we listen to others, we only reach a certain degree of approximation. When I describe my position, i.e. when I tell my story, I only approximate it. Even I myself do not fully own it. Even my own story, my own actions are apart from myself. My story is much bigger and wider and more encompassing than I present it at the time of speaking. Reality is always much more complex than my interpretation of it. Therefore, my interpretation may change. Therefore, I may tell my story differently in different contexts. Therefore, other people may tell my story differently from the way I did. If my speech turns "monolithic", it freezes and stops being alive.

When I listen to somebody, to their story or their points of view, I am only able to approximate it. I am able to enter their reality or their interpretation only to a certain degree. We cannot but leave the other person their singularity and also their strangeness.

"I am only able to get close to a stranger when I am capable to bear his remoteness", this is what Bernhard Waldenfels said in his fundamental work "Topographie des Fremden. Studien zur Phänomenologie des Fremden". [Topography of the stranger. Study of the phenomenology of that which is strange] (ROHR, 2005, p. 28).

But how does this process continue? During a discourse, I present my position, the other person presents her or his position, and we come closer. But even if we repeat these steps towards one another and find that we have come closer to each other in respect of some positions, distance and differences still remain. This is the time to look for a third point of reference beyond our positions.

We have heard that in respect of culture, this point of reference is the social behaviour in a given community. In our discourse, such a point of reference might then be: Which is the social behaviour that is appropriate for people today? What is it that could be contributed to useful social behaviour by my position or by your position? In order to answer 
this question, we will have to take into consideration the realities of life, the needs of life, and the suffering of humankind. When we exchange our points of view in a discourse, we will do so with an aim to become helpful to people. For this is the only way of creating realities of life.

In the context of religion, the third point of reference to be taken into consideration is the "ultimate reality". God is our counterpart when we meet as parties in a discourse. What does this mean for my position, what does it mean for your position that God is there as our counterpart, as a third entity? How does God's reality relativize your reality or mine? When we meet in His name, do we then have to compel agreement? Our discourse has an eschatological dimension as it will remain unfinished and fragmentary here on earth.

In order to achieve relation between people that are different and in conflicts, we are in need of communicative intercultural competences. In intercultural communication and in relationship-building, we are sure to experience many times that we lose confidence that we feel hurt, that we fail. Often, we are frustrated. Repeatedly, we end up in a crisis, or selfdoubt takes over. It is therefore, that how a German scholar says,

Intercultural competence means therefore, to put it in simple words, to be able to handle ones own as well as the others individual and cultural weaknesses, regressive and sometimes aggressive impulses, to bear feelings of impotency, fear of failure, feelings of insufficiency and if possible to turn the crisis into something productive and creative. It is therefore important to look at the crisis, the feeling of lost security and helplessness as a new chance, a different approach and a different way of understanding. The aim would be to find ways to meet and forms to communicate that endure intimacy and remoteness, touching and defence, understanding and non-understanding (ROHR, 2005, p. 28).

Intercultural competence is not acquired by accumulating intellectual knowledge, but only through a mutual process of learning among different people in different life situations. Intercultural competence thus means growing as a person who is able to stand proximity and to endure distance, one who acquires a tolerance of intimacy and distance. 


\section{Examples of interreligious pastoral care and counseling}

In the following, I would like to demonstrate the difficulties and possibilities of intercultural and interreligious pastoral care and counseling using transcripts of two conversations. They come from work in hospitals, a place where patients from different religious backgrounds come together. In the hospital, Christian chaplains and clergy come into contact with Christians from various confessions, atheists, Muslims, Buddhists and many others. The need for interreligious pastoral care and counseling is increasing also in other areas, such as schools and prisons. In order to help you understand the background of these conversations, I would like to make a few comments about pastoral care and counseling (chaplains) in Germany. This service generally does not reside directly within the structure of the hospitals; it is a service of the church - Roman Catholic or Protestant churches - and is also funded by the churches. Small denominations (free churches, Baptists, Methodists, etc.) offer this service in their own affiliated hospitals, but not everywhere. By law, the Roman Catholic and Protestant churches have the opportunity to offer and carry out pastoral care and counseling in hospitals. In larger hospitals (starting around 400 beds), there are usually full-time chaplains. This situation has advantages: Pastoral care and counseling is clearly defined as a service of the church and therefore has a clearly formed clerical profile. The disadvantage is that chaplains are anchored to the institutions but can still find themselves on the margins. It is often unclear what the institutions should do with these services. However, pastoral care and counseling is often gladly made use of by patients and workers.

At this point there are no non-Christian chaplains working fulltime in hospitals in Germany. Of course, patients are visited by their clergy, priests or spiritual leaders. But a continuous spiritual care only exists to a limited extent.

In the following two examples, full-time Christian chaplains encounter Muslims. They recorded these cases and presented them in groups in order to learn from them. There will be a reflection following the depiction of both cases. 


\section{A) "I saw Souls..."}

In the intensive care of a large hospital in a large city in Germany

S: fulltime Chaplain, around 45 years old, deacon of the Roman Catholic Church

P: patient, 41 years old, Pakistani, speaks good but somewhat broken German

P: had asked for a chaplain

S 1: Hello, I'm the chaplain. My name is X.

P 1: It's nice that you came. I was in a coma for ten days and my wife says that I experienced a lot, terrible things.

S 2: Tell me about it. I'll get a chair.

P 2: I made three trips. The first was with my ancestors. I saw souls, you know, souls, and I was in a church... (Seems like someone who tries to tell everything at once.) I don't know what it means.

S 3: You experienced a lot of internally exciting things in the coma. Tell me about it calmly, then we can sort things out some so that we can understand it better (I take more time for the patient than planned and mentally reschedule my lunch; I am satisfied with that).

P 3: The journey was with a ship. My ancestors were along and they steered the ship; I was sick. There were borders, soldiers inspected us.

S 4: You were afraid.

P 4: Yes, no one said anything; it was dismal.

Then we arrived at my country. You know, I come from Pakistan and they brought me back to the land that I come from. (Up to this point I had thought he was Indian based on his appearance.)

And suddenly I was in a church. There were souls there, you know, souls.

S 5: What did they look like?

P 5: Yes, souls, they were there.

S 6: Like humans, just that they didn't have a body and could walk through walls and everything?

P 6: Yes, it's good that you listen; there were so many and I don't understand it. 
S 7: You are becoming a little more calm and clear.

P 7: The church was not Pakistan, it was in Germany, in the city I lived in; I had been there a couple times at Christmas.

S 8: What kind of souls were they? Did they know you?

P 8: They were praying and I was sick, but they were praying that I would die and they wanted money from me. And I always say that they should forgive me, that I forgive them too. I also told my parentsin-law from my first wife that they should forgive me.

S 9: What should they forgive you for?

P 9: I got a divorce even though my wife didn't want one. She was a German.

S 10: Are your parents-in-law mad at you because of that?

P 10: I don't know them. They were already dead. Now they were there.

S 11: What did they say?

P 11: They didn't say anything. I said that they should forgive me.

S 12: You didn't say what they should forgive you for?

P 12: That I have my limitations and my pride; they should forgive me and I will forgive them.

S 13: It won't work like that.

P 13: They wanted me to die and I was supposed to pay money; they prayed that I would die.

S 14: That must have been terrible for you...

P 14: I was shaking...

S 15: You were afraid...

P 15: They were very angry with me. (Pause)

I believe in Jesus Christ, he is a prophet, it's in the Koran, I am a Muslim, Jesus was a prophet like Mohammed, he was sent by God.

S 16: But it wasn't your church that you were in...

P 16: No, I was there, we always went to church on Christmas, I believe in Jesus Christ, I lit candles in the church, in other churches that we went into too. There is only one God.

S 17: Yes. - What is the situation with you and God? Was he in the church too?

P 17: No. Up in heaven.

S 18: And God was looking down at you? 
P 18: He wants me to live. I have a new life. Prophets have travelled such journeys too. Maybe I now have special gifts from God, what should I do...

S 19: Yes, I too believe that God wants you to live.

$P$ 19: But what was with these souls? I'm afraid.

S 20: You need to leave this church but I know that you can't just leave; you have to find a way.

P 20: They don't let me leave. I know that I won't die but they are silent.

$S$ 21: I think that there is a big cultural difference here. Contrition plays a big role with us. Do you regret the things that should be forgiven here?

P 21: My pride, that is very important, I can't give it up.

$S$ 22: This could be difficult. Both of our cultures are clashing in your soul.

$P$ 22: The woman was not good. I now have a wife from Pakistan. I never had to say: "I'm hungry. Please get up and make me something to eat". She thinks: "My husband is coming home from work, I'm sure he's hungry," and makes me something to eat and it is done when I get home. (My hair starts to stand up on end.)

$S$ 23: I can imagine that your first wife was very different.

$P$ 23: As a man I have to be responsible for what happens in the family, accountable to God. I can't always discuss and do what a woman wants.

S 24: You know, with your first marriage you really engaged with our culture. Now you have big conflicts close by and haven't completely processed what happened. You will need to find peace...

$P$ 24: I have a good wife now...

S 25: That's good. I need to go now. This conversation was very interesting for me. Would you like for me to come again?

P 25: Yes, please come.

A couple days later I meet $P$ in a station with a three-bed-room. His wife is there. He wants to send her away so that I can sit next to him. I already have a chair in hand though and make clear that I want his wife to stay. That is not a problem.

After a couple of words I say... 
S 26: You are personally stuck between two very different cultures.

P 26: No, they are not cultures, I didn't feel wrong in this church, and it's the religions.

S 27: We could call it the religions if you like...

Once again P relates selected parts of his visions, this time many details. He hints that he understands them as a vision with which God has given him special gifts.

P 27: I sometimes see a glowing point in front of me which moves around the room.

S 28: What does the point remind you of, what does it look like?

P 28: Like a glow worm.

$S$ 29: And what does it do? Does it tell you something?

P 29: No, it sometime moves like this, sometimes like that. (I have to think about eye movements.)

$S$ 30: And when you close your eyes, is it still there?

P 30: Then it's gone.

S 31: Maybe it has something to do with your eyes, with seeing?

P 31: No, I don't think so.

$S$ 32: Do you think this is a sign from God?

P 32: (Nods). I have to tell you something. My wife rode here from another city with public transportation when I was in the coma. A woman approached her, a Jew, no a Buddhist, with a necklace and a star around her neck, she said to my wife: You have a very sick husband who is in a coma, there is someone that wants him to die, but he won't die, he will live. She said this right away and then got out of the train at the next station. My wife says it was an angel. Do you think that it was an angel?

S 33: It is possible.

P 33: We were so "spiritual" earlier. Those are spiritual forces that wanted to hurt me. What does it mean, tell me as a chaplain.

S 34: I'll say the following: you were very, very sick and standing on the edge of life and death. You saw that and received power from your roots, from your ancestors. 
P 34: But they were really concrete and like earlier, there weren't any cars and they were dressed so old...

$S$ 35: Yes, those are your roots; they reach back hundreds of years.

P 35: (Nods).

S 36: And the second thing that is important for this situation: you're alive. And you are alive because God wants you to live; he fought on your side. That is the foundation on which you can base your life from now on.

P 36: (Nods).

S 37: And there is still a poor relationship with your first wife.

P 37: Yes, (immediately starts to talk about the divorce, etc.).

$\mathrm{S}$ 38: You need to try to let go of this relationship, so that you are free from it.

P 38: That's not good for my wife (looks at her), that makes her sad.

S 39: Yes, try, maybe with a telephone conversation.

I have to go. We'll see each other again; I'll come by once more this week.

\section{Initial Questions}

It is immediately clear that this is a difficult conversation. What the patient says is really confusing. Are his pictures and dreams feverinduced fantasies? Do they have to do with his psychological situation caused by the serious illness? He is clearly in the situation in which he came close to death, and is processing his past - a painful past. Or does it seem like that which the patient relates is only confusing for the chaplain and has a clear logic which isn't understood?

To pose the question more concretely: What is the patient referring to when he talks about "travelling?" What does he mean by: "I have seen souls, you know, souls"? Is he processing current events in his life with his sentences ("The journey was by ship. My ancestors were along and they steered the ship; I was sick. There were borders and soldiers examined us"), about an escape, or are they a symbolic expression of his life, or are both mixed? 
The patient then brings the "Church" and his belief in "Jesus Christ" and "God" into the conversation. As a Muslim what does he mean to say by that? Is he trying to speak about his religiosity? Or is it about his experience with the church and with his Christian wife and his Christian parents-in-law? Does he want to emphasize the similarities between himself and the chaplain in order to establish a connection? Is he trying to underscore his faith, that he is not a bad person and innocent? Does he want to say that he did not deserve the illness?

In P 8, a marital conflict and a conflict with the parents-in-law and relatives becomes clear. Relationship conflicts, cultural distinctions and religious differences all blend together. How could they be unscrambled? The subject of "forgiveness," which is central for a Christian theologian, is touched upon. What meaning does it have for this Muslim? It is possible that a Muslim theologian would talk about it completely differently as this believer? Another point that makes communication difficult between the patient and chaplain is the understanding of gender roles. The chaplain's "hair stands on end" - a clear physical expression of disapproval.

The questions remain unresolved in the second conversation as well. In addition, the patient speaks of "the glowing point" as a "sign from God". And relates a story from the train where a woman becomes an "angel": a person between "psychic" and "satanic" powers.

Connected to the excurses concerning culture and religion, the conversation is concerned with the question of how these concepts are understood by the patient and chaplain. They play a role in the dialogue. I could imagine that a practicing orthodox Muslim could characterize the patient's comments as "non-Islamic" because there is little reference to devotion to God. Islamic piety, in turn, is quite familiar with the world of spirits and powers that appears here. Precisely, such religiosity can be a tremendous help for people in need. It is no different in Christianity. How could the chaplain talk about culture and religion in this situation in a way that leads to progress?

How should a chaplain deal with these questions? How can he be helpful in this situation? The patient pressures him to answer his questions. But has he understood the questions? Apparently not. 


\section{General Reflections}

\section{Biographies and cultural and religious views are always mixed}

In this encounter, various levels are clearly present at the same time: the biography as an emigrant, descent from a foreign land, familial ties to the original family and to the German relatives, relationship conflicts in the marriage, serious illness, cultural and religious differences and emotional sensitivities like fear (also of death), disappointment (over a broken marriage), aggression (towards the first wife and the parentsin-law) and satisfaction ("now I have a good wife") are interwoven. That means we never have a cultural or religious perspective without a personal or biographical perspective. The personal biography interprets culture and religion, culture and religion determine and interpret the personal history and situation. The patient cannot separate these aspects. The chaplain tries to make the different levels clear, which only helps the patient understand his experiences to a certain extent.

\section{The importance of emotions for relationships}

The attitude of not knowing is very important in intercultural and interreligious encounters. The experience described is so foreign to the chaplain that he can hardly understand - it is probably not any different for us readers. But how should I act if I don't understand? Should I ask questions? Should I have him explain that which is strange for me? At any rate, I can't act as though I understood. It is also not helpful to interpret what is said based on my own presuppositions and my own experiences. However, I can judge how what is said affects me. It appeals to me that the patient uses many images to express his experiences and emotions. He sees "souls," that is spirits, who are close to him and pressure him but also protect him. What he means is unintelligible; at any rate, these "souls" provoke emotions in the patient. Perhaps they are even an expression of his feelings. Would it have been helpful to ask him about that? He tells of 
a journey on "a ship with the relatives". While in great danger, the relatives surround him. Do they give him a sense of security or do they make him afraid? I would have liked to ask him. The next image, "the souls in the church," is emotionally charged as well. Although it is very hard to understand on the rational level, there might be a way to come closer emotionally, if one pays attention to the feelings in the comments and images. Emotions lie deep in our "consciousness" as biological and physical messages about our experiences. Feelings can establish relationships to others where "understanding" fails. This is quite evident in relationships with children. I am convinced that this is also a possibility in encounters with people from other cultures, religions or different biographies.

\section{Support relationship despite differences}

The differences experienced by the patient and the chaplain are not easy to bear. But tolerating differences is an important element of the relationship. Time and again the patient tries to enter into a relationship with the chaplain. At the same time, the differences cannot be overcome. The way of expressing oneself and understanding, as well as the experiences, are too disparate. It is a hard request to ask of people to stay in a relationship and tolerate each other in such a situation. If it is possible and successful, then both partners gain. The patient did not succeed in this aspect with his first marriage. Both of them came from different walks of life and remained in them to an extent that they had to separate. For the man from Pakistan, marriage meant that the man has the responsibility and the woman orients herself around the man; therefore the woman has to adjust to the man's worldview. Counseling can help form relationships without passing over the differences. The differences make differentiation possible in the first place and show us the possibilities and the richness of human experience and existence. These abundances and the diverse possibilities can be discovered and made productive through intercultural and interreligious work. 


\section{The Discussion in a study group: discerning foreignness and entering into a Relationship}

This transcript was introduced and discussed in a discussion group in a course that I led. The transcript was initially discussed like all others. I usually proceed by having everyone in the group express how they were affected emotionally after the transcript has been read. The chaplain's confusion was reflected in the group's comments. I heard many of the questions mentioned above. In the next step of the discussion, the chaplain said what he wants to continue working on. The deacon wanted to understand more clearly what the patient could have meant in order to gain access to him. At this point, the group's fantasies diverged greatly. In the end, however, it was clear that this was not helpful because the fantasies could not be clarified by the patient. We then came to the man's cultural and religious outlooks, which caused reactions of defensiveness and astonishment. Once again, this reflected the chaplain's reactions. While the group was occupied with the patient and his images early on, the discussion turned more and more to the chaplain. It emerged that the participants also felt unsure of themselves and helpless. This comforted the chaplain; he felt solidarity with the others. The man's foreignness in his attitudes, his cultural and religious influences and his path of life - in contrast to that of the course participants - was recognized and experienced. It was important to not ignore or skip over this foreignness and this being different, but rather to appreciate it. It was important to experience the differences that played an important role for the man in the conversation. Only after the foreignness was recognized did the first approaches begin to engage the man at an emotional level. The chaplain had rudimentarily attempted this couple of times (S 4; S 14), but overall he asked about what he should do to understand rationally, or he instructed. Now, with the group he began to listen more to his own emotionality in relation to the man - and it emerged that an "understanding" arose. It was an emotional approach to the patient's confusion, the fear and the insecurity. The stranger became a confidant and a human came into view with his humanity.

The result of this group discussion was: even with all the cultural, religious and biographical differences, interreligious counseling aims to 
perceive and accept the person in his or her humanness. It must be noted, though, that this succeeds sometimes, and sometimes it does not. It is most likely to succeed when it is possible to let someone in emotionally and enter into a relationship with them.

\section{Closing theological reflections}

The fact that chaplains orient themselves around the patient's humanity and do not specifically bring their convictions into the conversation can be theologically justified by Christian views in various ways. I would just like to hint at them here:

a) Seeing people as God's creation applies to the interpersonal devotion.

b) God becoming man in Jesus Christ (incarnation) reminds us that everyone is a child of God.

c) God's Spirit leads us in humanity and towards an appreciation of humans in their own ways.

Chaplains can also introduce their own religious beliefs and interpretations as an expression of the search for meaning and salvation into interreligious and intercultural counseling, if it seems helpful for the context, situation and relationship. However, its main concern should always be to try to help the other person to reach his or her own meaning and own salvation.

\section{Conclusion}

A few theses in conclusion:

Interreligious and intercultural pastoral counseling is contextual counseling. The cultural and religious context of the respective persons is realized, observed and brought into the relationship. 
Interreligious and intercultural pastoral counseling recognizes differences on all levels of human relationships. The biographical and confessional differences are tolerated and not ignored. Despite this, counseling seeks connections and interpersonal similarities.

Interreligious and intercultural counseling is rational and emotionbased relationship work. In all areas of difference, counselors and conversation partners should look for points of mutual contact in understanding and - the places where everyone is the same.

Interreligious and intercultural counseling takes place on the backdrop of a "last reality" and receives its theological practice and understanding from it.

Interreligious and intercultural counseling always has to be reconceived and reformulated in each societal context and is therefore oriented around the current situation and seeks its meaning in the future.

\section{References}

Augsburger, D. W. Pastoral Counseling across Cultures. Philadelphia: The Westminster Press, 1986.

BAR-ON, D. Die “Anderen” in uns: Dialog als Modell der Interkulturellen Konfliktbewältigung. Hamburg: Körber-Stiftung, 2003.

GEERTZ, C. The interpretation of cultures. New York: Basic, 1973.

ROHR, E. Intercultural competence. In: INTERCULTURAL AND INTER-FAITH COMMUNICATION, MATERIALS FROM THE INTERNATIONAL SEMINAR, 13., 2006, Düsseldorf. Proceedings... Düsseldorf: Magazine of SIPCC; Intercultural Pastoral Care and Counselling, 2006.

Theissen, G. Die Religion der ersten Christen: Eine Theorie des Urchristentums. Gütersloh: Kaiser, Gütersloher Verl.-Haus, 2001.

SCHIPANI, D. S.; BUECKERT, L. D. Interfaith spiritual care. Understandings and practices. Kitchener: Pandora Press, 2009. 
WATZLAWIK, P. et al. Menschliche Kommunikation: Formen, Störungen, Paradoxien, Bern, Switzerland, Verlag Hans Huber, 1974. The German translation of, Pragamtics of Human Comminication. A Study of Interactional Patterns, Pathologies, and Paradoxies. New York: W. W. Norton and Company Inc., 1967.

WEISS, H. Die Entdeckung Interkultureller Seelsorge. In: FEDERSCHMIDT, K. et. al. Handbuch Interkulturelle Seelsorge. Neukirchen-Vlyun: Neukirchener Verlag, 2002. p. 17-37.

WEISS, H. Interreligious and intercultural pastoral care and counseling. Notes from a German perspective. In: SCHIPANI, D. S.; BUECKERT, L. D. Interfaith spiritual care: understandings and practices. Kitchener: Pandora Press, 2009. p. 235-258.

Recebido: 17/12/2010

Received: 12/17/2010

Aprovado: 17/01/2011

Approved: 02/17/2011 